Research

\title{
Risk Assessment of The Use of Colistin Sulfate In Broiler Due To Escherichia coli Resistance In Broiler Flocks
}

\author{
Maria Fatima Palupi ${ }^{1^{*}}$, Etih Sudarnika², I WayanTeguh Wibawan², \\ Huda Shalahudin Darusman ${ }^{3,4}$, Hera Maheshwari ${ }^{3}$ \\ ${ }^{1}$ National Veterinary Drug Assay Laboratory, Directorate General of Livestock and Animal Health, \\ Ministry of Agriculture of the Republic of Indonesia, Bogor, Indonesia \\ ${ }^{2}$ Department of Animal Disease and Veterinary Public Health, Faculty of Veterinary Medicine, \\ IPB University, Bogor, Indonesia \\ ${ }^{3}$ Department of Anatomy, Physiology, and Pharmacology, Faculty of Veterinary Medicine, \\ IPB University, Bogor, Indonesia \\ ${ }^{4}$ Primate Research Center, \\ IPB University, Bogor, Indonesia \\ *Corresponding author: lupi ima@yahoo.co.id \\ Submitted 7 November 2019, Accepted 22 December 2019
}

\begin{abstract}
The risk assessment of antimicrobial resistance is very important to determine the risk of decreasing antimicrobial efficacy can be used as a basis for policymakers in allowing or prohibiting the use of an antimicrobial. This study aims to assess the risk of using colistin against E. coli resistance in the broiler flock. Risk assessment is carried out qualitatively using primary data, interviews, and secondary data. To obtain primary data various studies were carried out including monitoring the prevalence of colistin-resistant E. coli and mcr-1 also mcr-2 genes in broiler flocks, mcr-1 gene transfer from E. coli to Salmonella Enteritidis, mcr-1 gene sequencing, mutant selection windows of colistin against E. coli, and also multiresistant of $E$. coli colistin-resistant. Assessment of the risk of $E$. coli colistin-resistant in the broiler flocks through direct contact with live broiler flock environment with the resulting assessment is a medium risk with low uncertainty. Since colistin sulfate is very critically important for humans, the reduced use of colistin sulfate in animal production is necessary to reduce the risk of resistance. Reducing the use of colistin sulfate requires the collaboration of various sectors such as the government, veterinary drugs industries, farmers, and consumers.
\end{abstract}

Keywords: colistin sulfate, mcr-1, risk assessment, resistance, broiler

\begin{abstract}
ABSTRAK
Penilaian risiko resistansi antimikrob sangat penting untuk menentukan risiko yang disebabkan penurunan daya efikasi antimikrob dan dapat digunakan sebagai dasar ilmiah bagi pemerintah untuk melarang atau mengijinkan penggunaan suatu antimikrob. Tujuan dari penelitian ini adalah untuk menilai risiko penggunaan kolistin terhadap resistansi kolistin pada E. coli di flok broiler. Penilaian risiko dilakukan secara kualitatif dengan menggunakan data primer, wawancara, dan data sekunder. Untuk mendapatkan data primer dilakukan berbagai penelitian, antara lain monitoring prevalensi E. coli resistan kolistin, gen mcr-1, serta mcr-2 di kandang broiler, transfer gen mcr-1 dari E. coli ke Salmonella Enteritidis, sekuensing gen mcr-1, mutant selection windows kolistin terhadap E. coli, dan multi resistansi $E$. coli resistan kolistin. Hasil penilaian risiko E. coli resistan kolistin pada flok broiler melalui kontak langsung dengan broiler hidup dan lingkungan kandang adalah medium dengan ketidakpastian rendah. Kolistin sulfat sangat penting bagi manusia oleh sebab itu penurunan penggunaan kolistin sulfat di hewan produksi harus dikurangi untuk menurunkan risiko akibat resistansi. Penurunan penggunaan kolistin memerlukan kerjasama berbagai sektor seperti pemerintah, industri obat hewan, peternak, dan konsumen.
\end{abstract}

Kata kunci: kolistin sulfat, mcr-1, penilaian risiko, resistansi, broiler 


\section{INTRODUCTION}

The use of colistin sulfate in food production, which is the last drug choice for human as treatment of multiresistant gram-negative bacterial infections, raise a high interest in the world. Especially since the discovery of the mobilized colistin resistant-1 (mcr-1) gene that can be transferred via plasmids in 2015 by Liu et al. (2015). This gene is transmissible to other bacteria and causes many countries to begin to reduce the use of colistin sulfate in animal production. Nevertheless, the prohibition on the use of an antimicrobial must go through scientific studies to produce valid results, such as by risk assessment.

Risk assessment is part of a risk analysis that is very helpful for the government in making policies that are useful for assessing and managing risks to human and animal health regarding the increased antimicrobial resistance used in animals (OIE 2016). Antimicrobial risk assessment based on CODEX (2011) consists of hazard identification, hazard exposure, hazard characterization, and risk characterization. Until the time this research began, studies on the assessment of the risk of bacterial resistance due to the use of antimicrobials in production animals qualitatively and quantitatively have never been done in Indonesia.

We consider, along the supply chain of broiler meat, there are four main pathways of resistantcolistin E. coli exposes to humans. The first pathway is in broiler flocks, the second pathway is at a small slaughterhouse, the third pathway is in traditional markets through broiler fresh meat, and the last pathway is through broiler cooked meat products. In this paper, we only present an assessment of the risk of exposure to colistin-resistant $E$. coli in broiler flocks. The purpose of this study was to conduct a qualitative risk assessment of colistin sulfate on the emergence of colistin resistance in $E$. coli in broilers regarding the risk of human exposure to colistinresistant E. coli in broiler flocks. It is hoped, this risk assessment can be used as consideration for determining the continued use of colistin sulfate in food animals, especially broilers in Indonesia.

\section{MATERIAL AND METHODS}

The study was conducted from November 2016 until January 2019 and principally generate primary and secondary data. Primary data collection was carried out by in vivo and in vitro effect of colistin sulfate exposure on $E$. coli resistance, conducting broiler supply chain modeling experiments in the laboratory, sampling in 47 flocks that use colistin sulfate (cloacal swabs, drinking water, and litters) to obtain the prevalence of colistin-resistant E. coli as well as mcr-1 and mcr-2 genes in 5 districts in BogorIndonesia, serotyping of E. coli $\mathrm{O} 157: \mathrm{H} 7$, questionnaires, expert opinions, gene transfer mcr-1 to $S$. Enteritidis, sequencing of the mcr-1 gene, multiresistance of $E$. coli resistance colistin isolates, and mutant prevention concentration (MPC) research. The collection of secondary data was conducted thorough studies of scientific publications, unpublished data, and expert opinions. The risk assessment was made by using the data above to generate a qualitative risk assessment that developed from CODEX (2011) dan EMA (2018). Some parts of those researches have been published separately (Palupi et al. 2018 ; Palupi et al. 2018 , and Palupi et al. 2019).

\section{Hazard Identification, Exposure Assessment, and Hazard Characterization}

To conduct hazard identification, various information about colistin sulfate and $E$. coli are needed, such as the prevalence of colistin-resistant $E$. coli, determination of resistance, the occurrence of cross-resistance or co-resistance, and minimum inhibitory concentration (MIC) data of colistin sulfate against $E$. coli. The information needed in the exposure assessment of colistin-resistant E. coli includes the description of colistin veterinary drug products circulating in Indonesia, the use of colistin in broilers, suppression of colistin resistance selection, the occurrence and rate of transfer of resistance, colistin concentration in the intestine lumen, selective windows of colistin sulfate, the prevalence of colistin-resistant $E$. coli from living and environmental broilers, and personnel characterization that can be directly exposed to colistin-resistant E. coli (Codex 2011, EMA 2018)

The information needed in assessing the hazard characterization of colistin-resistant E. coli from broilers to humans is the use of colistin sulfate for humans and the consequences if humans are exposed to colistin-resistant $E$. coli. The required details include the presence of colistin sulfate and its alternatives, the prevalence of colistin-resistant bacterial infection in humans, and the horizontal spread of resistance.

The Likelihood Categorization of Exposure Assessment and Risk Characterization

Qualitative risk assessment was analyzed according 
to the stages in the CODEX CAC / GL 77-2011 document: Guidelines for Analysis of Foodborne Antimicrobial Resistance. Explanation or interpretation of hazard assessment is presented in Table 1.

The results of the exposure assessment are obtained by making a likelihood assessment of each node in the pathway of exposure. The exposure assessment of each pathway was carried out using a combination of the likelihood combination matrix in Table 2 that developed from AFFA (2001).

If multiple exposures are found in the pathway, the overall qualitative risk scoring for the exposure assessment is as follows: (1) if one of the partial risks is high, then the overall risk is also high; (2) if more than one partial risk is medium, overall risk is high; (3) if one partial risk is medium and the other partial risk (more than one) is low, the overall risk is high; (4) if there is one medium partial risk and the other partial risk is not medium, then the overall risk is medium; (5) if all partial risks are low, overall risk is medium; (6) if one or more partial risks is low, overall risk is low; and (7) if all partial risks can be neglected, the overall risk is negligible.

After conducting exposure assessment, the next step is to conduct a hazard characterization assessment. Interpretations of hazard characterization assessments are listed in Table 3. In a qualitative risk assessment is important to understand the level of uncertainty of the information used. Categorization of information uncertainty using EFSA (2006), which are low, medium, and high uncertainty. The final step in assessing risk is to assess risk characterization. Risk characterization assessment is done by combining the results of exposure assessment and hazard characterization is presented in Table 4 (CODEX 2011).

\section{RESULTS AND DISCUSSION}

Hazard Identification: Colistin sulfate and Colistinresistant Escherichia coli

Colistin sulfate is a polymixin antibiotic used in animals and humans. Since 2017, polymyxin is categorized as the Highest Priority Critically Important Antimicrobials for Human Medicine (WHO 2017). Colistin sulfate has been used for decades in food animals as a therapy, prevention of infection, and as growth promotor. Colistin is very difficult to absorb by the digestive tract of broiler chickens (Lashev and Haritova 2003). Some commercial colistin sulfate veterinary drugs contain a single colistin sulfate and some are combined with other antimicrobials (EMA 2013; DGLAHS 2016).

Escherichia coli is a commensal bacterium that very important in monitoring and surveillance antimicrobial resistance in food animals and their products. The commensal bacterium is considered as a reservoir of antimicrobial resistance genes, which can transfer these genes to pathogenic bacteria (OIE 2016). Meanwhile, Escherichia coli serotype O157: H7 is a pathogenic zoonotic bacterium for humans (Riemann and Cliver 2006; Ferens and Hovde 2011). Food animals along with their products and their environments also considered a factor in the increasing or spreading of resistant bacteria.

Table 1 The qualitative interpretation of likelihood human exposure to colistin-resistant Escherichia coli

\begin{tabular}{ll}
\hline Assessment & \multicolumn{1}{c}{ Interpretation } \\
\hline Negligible & The probability of exposure for susceptible people is extremely low so it can be negligible \\
Low & The probability of exposure for susceptible people is low but possible \\
Medium & The probability of exposure for susceptible people is likely \\
High & The probability of exposure for susceptible people is certain or very high \\
\hline
\end{tabular}

Table 2 Likehood matrix combination of exposure assessment of colistin-resistant E. coli

\begin{tabular}{ccccc}
\hline \multirow{2}{*}{ Likelihood 2 } & \multicolumn{4}{c}{ Likelihood 1 } \\
\cline { 2 - 5 } & High & Medium & Low & Negligible \\
\hline High & High & Medium & Low & Negligible \\
Medium & Medium & Low & Low & Negligible \\
Low & Low & Low & Negligible & Negligible \\
Negligible & Negligible & Negligible & Negligible & Negligible \\
\hline
\end{tabular}


Table 3 Interpretation of likelihood assessment of hazard characterization colistin-resistant Escherichia coli qualitatively

\begin{tabular}{|c|c|}
\hline Categories & Interpretation \\
\hline Negligible & No adverse human health impact or consequences \\
\hline Low & Symtoms are minimally bothersome and no therapy are needed \\
\hline Medium & $\begin{array}{l}\text { Symtoms are more pronounced than low categories but not life threatening. If an infection } \\
\text { occurs, treatment is needed as indicated. }\end{array}$ \\
\hline High or severe & $\begin{array}{l}\text { Symtoms are potentially life threatening and requaire systemic treatment or hopitalization. } \\
\text { Increase severity may occur due foodborne resistant bacteria. }\end{array}$ \\
\hline Very highor fatal & $\begin{array}{l}\text { Directy or indirectly contributes to the death infected patient, treatment failure is likely } \\
\text { expected due to foodborne resistant microorganism. No alternative treatment beside using } \\
\text { colistin sulfate }\end{array}$ \\
\hline
\end{tabular}

Table 4 Matrix combination of risk characterization assessment colistin-resistant Escherichia coli

\begin{tabular}{cccccc}
\hline \multirow{2}{*}{ Exposure assessment } & \multicolumn{5}{c}{ Hazard characterization } \\
\cline { 2 - 5 } & Negligible & Low & Medium & High & Very hlgh \\
\hline Negligible & Negligible & Low & Low & Low & Low \\
Low & Negligible & Low & Low & Medium & High \\
Medium & Low & Medium & Medium & High & Very high \\
High & Low & Medium & High & Very high & Very high \\
\hline
\end{tabular}

The mechanism of resistance of $E$. coli to colistin is known through (1) mutations in specific regions, such as pmrA / B and phoP / Q, (2) mutations in the structure of lipopolysaccharide in the cytosol (ParRParS system), and (3) addition of phosphoethanolamine to lipid $A$ that mediated by the mobilized colistin-resistant ( $\mathrm{mcr}$ ) genes (Fernández et al. 2010; Moskowitz et al. 2012; Liu et al. 2015). Co-resistance can occur with other polymyxin groups and several cationic peptides (Napier et al. 2013; Catry et al. 2015).

The spread of the mcr-1 gene can be through plasmids or conjugation, transposon composites, transformation, and chromosomes (Hadjaj et al. 2017; Lima Barbieri et al. 2017; Tada et al. 2017 ; Sun et al. 2018). Our study also succeeded in transferring this gene from colistin-resistant E. coli to S. Enteritidis ATCC 13076 through conjugation (Palupi et al. $2018^{\mathrm{a}}$ ). Escherichia coli is the most common bacteria found to have mcr-1 gene (Poirel et al. 2016).

Our study showed that the prevalence of colistinresistant E. coli along the broiler supply chain in Bogor was $11.76 \%$ (95\% Cl; CL 9.21-14.91\%) with mcr-1 gene prevalence of $10.55 \%$ (95\% Cl; CL $8.13-13.57 \%$ ) (Palupi et al. 2019). Our study also showed a very high agreement between colistin-resistant phenotype and mcr-1 genes genotype (89.66\% conformity with a value of $к$ 0.939), we didn't find mcr-2 gene, the MIC value of $E$. coli susceptible to colistin sulfate was $0.125-2 \mu \mathrm{g} / \mathrm{mL}$, and the MIC value of colistinresistant E. coli was 4 to $>32 \mu \mathrm{g} / \mathrm{mL}$.

\section{Exposure Assessment Colistin-resistant Esche- richia coli to Humans in Broiler Flocks}

Food animals and their environment are considered as one reservoir of resistant bacteria that can transfer directly or indirectly to humans (Marshall and Levy 2011; WHO 2016). We consider two major exposure branches pathway in the pathway exposure of colistin-resistant $E$. coli to humans in broiler flocks. First branches are through direct contact with live broilers and second branches are exposure through flock environment that contaminated with colistin-resistant E. coli (Figure 1). Assessment of exposure through direct contact with live broilers involves two likelihood nodes, the first node is colistin-resistant $E$. coli in broilers due to the usage of colistin sulfate in the broiler (L1) and the likelihood of the process of human get exposed to colistinresistant E. coli from live broilers (L3). The exposure pathway through the flock environment involved 3 likelihood nodes which are colistin-resistant E. coli derived from broilers (L1), the likelihood of flock environment get contaminated with colistinresistant E. coli (L2), then the likelihood of colistinresistant $E$. coli exposes humans through contact with the flock environment $(L 3)$. 


\section{Exposure Pathway of Colistin-Resistant $E$. coli to Humans in Broiler Flocks}

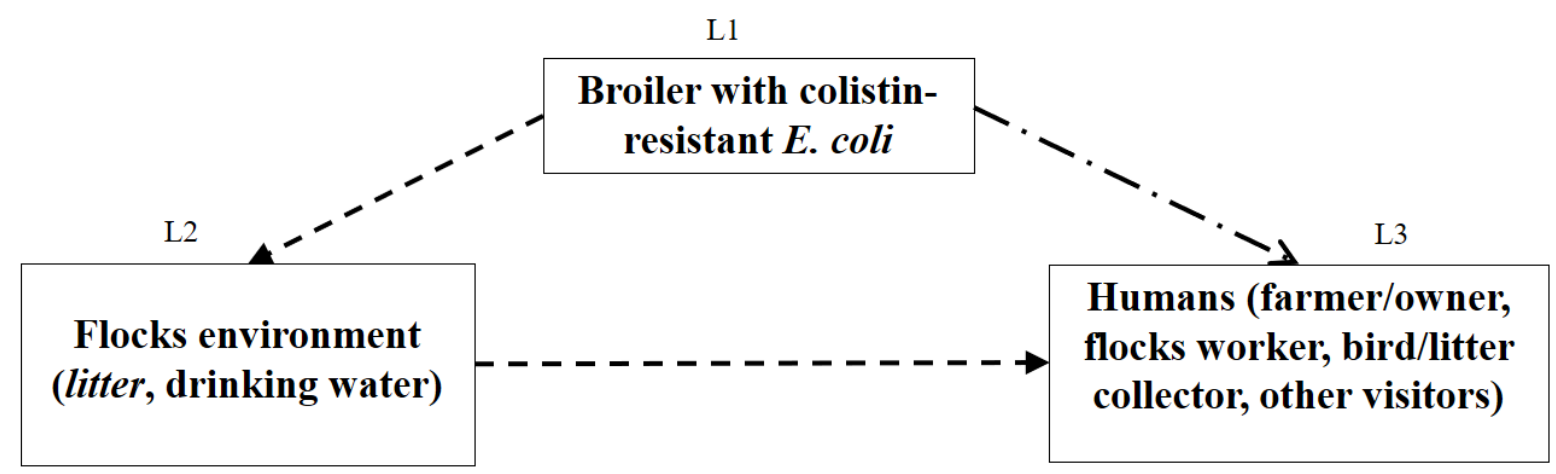

Figure 1 Exposure pathway resistant-colistin E. coli to human in broiler flock. The first exposure is through direct contact with live broiler ( $L 1 \times L 3)$ and the second is through the environment at flocks $(\mathrm{L} 1 \times \mathrm{L} 2 \times \mathrm{L} 3)$

Likelihood Assessment Broiler with Colistin-

Resistant Escherichia coli Due The Usage of Colistin Sulfate (L1)

Based on observations and questionnaires, personnel who can contact with chickens and the flocks environment are flock workers, health technical services (eg veterinarians), one-day-old chicken (DOC) senders, broiler collectors, broiler catchers, and litter collectors. Direct contact between broilers and humans in the flock, intensively occurs when the chick in, checking the weight (once a week), and the harvest period.

Commercial E. coli is very rarely found in DOC. In our study (Palupi et al. 2018a), only 5.56\% DOC was found with commensal $E$. coli and none were resistant to colistin. At the time of harvest, the personnel most frequently contacted with broilers are flock workers, bird collectors, and bird catchers. Other visitors who can contact the broiler in the flock are technical health service (25.5\%) and DOC sender (25.5\%).

Broiler farmworkers generally do not wear personal protective equipment (PPE) when working, eg. gloves, boots, wear packs, or masks (Figure 2). Visitors are also not provided with personal protective equipment. After working, 42.6\% of workers simply cleaned themselves with water, $42.6 \%$ cleaned themselves with soap, and only $14.8 \%$ cleaned themselves with soap and with disinfectants, such as $70 \%$ alcohol.
The personnel most often in contact with litter and drinking water are flock workers. There is a litter collector that takes the litter when the broiler harvest is finished. When collecting litters, they do not use adequate PPE. Information on the use of PPE is crucial in taking litter because litter is a good medium for the development of pathogenic microbes. Escherichia coli 0157: $\mathrm{H} 7$ can survive in the litter for 42-49 days at $37^{\circ} \mathrm{C}, 46-56$ days at $22^{\circ} \mathrm{C}$, and $63-70$ days at $5^{\circ} \mathrm{C}$ (Solimanet et al. 2018).

Based on the assessment of the characteristics of $E$. coli, the prevalence of colistin-resistant $E$. coli with mcr-1 gene, resistance distribution patterns, raising management of broiler, and biosecurity practices in broiler flocks, colistin-resistant E. coli with mcr-1 gene may expose humans. Research conducted by Trung et al. (2017), showed that farmers who were exposed to broiler positive mcr-1 showed a higher risk of colonization of bacteria carrying mcr-1 than those that were not directly exposed to chickens or with farmers whose chickens did not have the mcr-1 gene.

Humans who are most likely to be exposed are flockworkers, then bird catchers, and litter collectors. Based on the evaluation of the information, the $L 3$ exposure assessment is medium with low uncertainty. The uncertainty of information in making this exposure assessment is low because based on references, observations that give the same results, and interviews with experts also give the same opinion. 


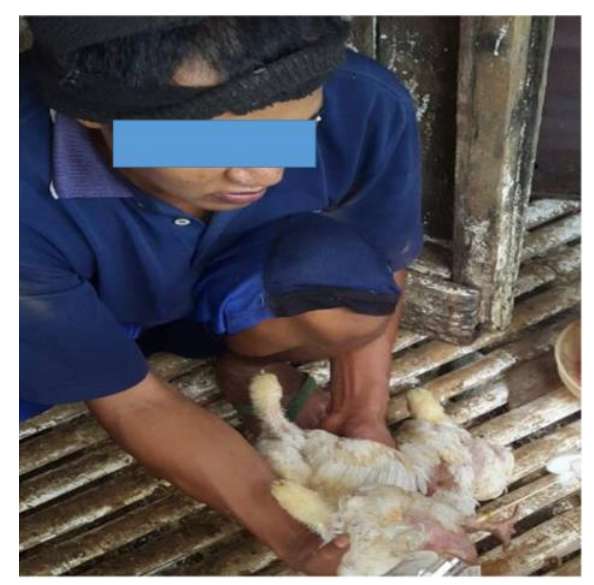

Figure 2 Flockworkers do not use proper PPE

Results of Likelihood Exposure Assessment of Colistin-resistant Escherichia coli to Humans in Broiler Flocks

Calculation of likelihood for human exposure by colistin-resistant $E$. coli from broilers flocks is obtained using a combination matrix of Table 2. The results of the likelihood exposure assessment of colistin-resistant $E$. coli to humans through direct contact with broilers (first branch pathway) are low with low uncertainty. This low assessment is obtained from the possibility of L1 (medium) $\times$ L3 (medium).

The likelihood of human exposure assessment by colistin-resistant $E$. coli through the flock environment is low, this likelihood exposure assessment involves L1 (medium) x L2 (low) x L3 (medium). The uncertainty through this pathway is also low. Low uncertainty assessment based on the majority of information sources obtained based on primary data, references that are very supportive and not contradictory, questionnaire results, and expert opinions that do not conflict with each other. The overall exposure assessment of colistin-resistant E. coli to humans at the broiler flock level uses the principle of multiple exposures in that the values are medium (low + low) with low uncertainty (Table 5).

\section{Hazard Characterization of Human Exposure by Colistin-Resistant Escherichia coli in Broiler Flock}

Information for hazard characterization is obtained through scientific publications and direct communication with Dr. Harry Parathon, SpOG (K). The use of colistin in Indonesia is very limited because it is used as the last drug choice for the treatment of pan-resistance. Colistin for the treatment of panresistant cases is difficult to obtain but in some large hospitals, it is provided as alternative medicine. Based on communication in July 2018 , colistin methanosulfonate (injection) has not yet included in the health system and is likely to be held in the coming year. Based on communication with experts, it was mentioned that the prevalence of cases of panresistant human infection in Indonesia is still very low.

The prevalence of colistin-resistant E. colipositive mcr-1 gene infections in hospitalized patients has been studied in several countries and ranges from 0\% - 1.4\% (Kim et al. 2017; Terveer et al. 2017; Principe et al. 2018). The higher prevalence is indicated by Eiamphungporn et al. (2018) in Thailand, reaching $27.7 \%$. In the hazard characterization assessment of E. coli zoonosis, our study used E. coli serotype O157: H7. Colistin-resistant E. coli O157: H7 isolates with $\mathrm{mcr}-1$ gene were only found in one isolate out of a total of $380 \mathrm{E}$. coli isolates from live broiler and flock environment $(0.31 \%)$ or the prevalence was very low. Several studies have shown that colistin-resistant $E$. coli with mcr-1 from food animals and pets can move to humans (Olaitan et al. 2015; Zhang et al. 2016; Tada et al. 2017 ${ }^{\mathrm{b}}$ ).

In our study, $95.59 \%$ of colistin-resistant E. coli isolates were also found to be multiresistant (Palupi 2019). Colistin-resistant E. coli infections can still be treated with other antibiotics as long as the infecting bacteria are not multiresistant to the antimicrobial used. Therefore, based on the information obtained, the hazard characterization assessment of human exposure by colistin-resistant E. coli in broiler flocks is medium with low uncertainty. 
Table 5 Recapitulation of exposure assessment colistin-resistant Escherichia coli to humans in broiler flock

\begin{tabular}{lcr}
\hline \multicolumn{1}{c}{ Pathway description } & Assessment & Uncertainty \\
\hline $\begin{array}{l}\text { Exposure of colistin-resistant E. coli to humans in broiler flock } \\
\text { through direct contact with broilers }\end{array}$ & Low & Low \\
$\begin{array}{l}\text { Exposure of colistin-resistant E. coli to humans in broiler flock } \\
\text { through direct contact with the flock environment }\end{array}$ & Low & Low \\
\hline Total exposure assessment (first + second branch pathway) & Medium & Low \\
\hline
\end{tabular}

Table 6 Assessment of the risk characterization of colistin-resistant in Escherichia coli in the broiler flocks to humans

\begin{tabular}{lcccc}
\hline \multirow{2}{*}{ Description exposure pathway } & \multicolumn{4}{c}{ Likelihood } \\
\cline { 2 - 5 } & $\begin{array}{c}\text { Exposure } \\
(\mathrm{E})\end{array}$ & $\begin{array}{c}\text { Hazard characteriza- } \\
\text { tion }(\mathrm{H})\end{array}$ & $\begin{array}{c}\text { Risk characterization } \\
(\mathrm{E} \times \mathrm{H})\end{array}$ & Uncertainty \\
\hline $\begin{array}{l}\text { Exposure of colistin-resistant } \\
\text { E. coli to human in broiler flock }\end{array}$ & Medium & Medium & Medium & Low \\
\hline
\end{tabular}

\section{Risk Characterization of Colistin-Resistant Esche- richia coli in Broiler Flock to Humans}

The final step in risk assessment is to carry out risk characterization based on exposure assessment pathway and hazard characterization assessment. The risk characterization assessment uses a combination of exposure assessment and hazard characterization matrix as in Table 4. The results of the risk characterization exposure assessment through the broiler flock are medium (medium $x$ medium) with low uncertainty. The results of the risk characterization assessment are in Table 6.

\section{Risk Mitigation of Colistin-Resistant Escherichia Coli from Broiler Flocks to Humans Health}

The veterinary medicine industry plays an important role in the circulation of colistin sulfate. Fulfillment of pharmacological data and colistin sulfate resistance from animal drugs to be registered must be tightened based on scientific data per product. In 2016 the European Committee for Medicinal Products for Veterinary Use (CVMP) requested that all colistin sulfate combinations with other oral antimicrobials be withdrawn from the European Union (EMA 2016). Approval for the registration of animal drug colistin sulfate combined with other antimicrobials must go through in-depth scientific evaluation.

Good farm management will reduce the risk of pathogenic bacterial infection. This will reduce the dependence of farmers on antimicrobials to prevent infection. The use of proper PPE to reduce the risk of direct contact with colistin-resistant E. coli also needs to be done when handling chickens, working, and taking litter in the farm. The use of PPE will greatly help reduce risks, especially for small scale broiler farms which are difficult to implement in three zones of livestock.

Education about the position of colistin sulfate to farmers or health managers on broiler farms is also very important. Farmers and health managers need to understand the importance of colistin for human health so as not to choose colistin sulfate as the first choice in handling cases of gram-negative bacterial infections in broilers.

\section{CONCLUSION}

Risk assessment of colistin-resistant $E$. coli risk in broiler flock through direct contact with live broilers and the enclosure environment to humans is medium with low uncertainty. This is due to the use of colistin sulfate which is the highest priority critically important antimicrobials for humans in broilers, the presence of the mcr-1 gene that is easily transferred between bacteria, low biosecurity at the farm, contamination in the farm environment, and low use of PPE in the farm. Therefore, reducing the use of colistin sulfate in production animals is a necessity that cannot be avoided. 


\section{ACKNOWLEDGEMENTS}

We thank to director and all staff at Pharmaceutical-Premix and Bacteriology Laboratory of NVDAL for their support. We are also grateful to the Agency for Agricultural Extension and Human Resources Development (AAEHRD) - Ministry of Agriculture of the Republic of Indonesia that has provided scholarships and research funds.

"All authors declare that there are no conflicts of interest".

\section{REFERENCES}

[AFFA] Agriculture, Fisheries and Forestry Australia. 2011. Guidelines for Import Analysis Draft September 2011. Biosecurity Development and Evaluation Biosecurity Australia

Amaral LA. 2004. Drinking water as a risk factor to poultry health. Brazilian J Poult Sci. 6(4):191-199.

Blondeau JM, Hansen G, Metzler K, Hedlin P. 2004. The role of PK/PD arameters to avoid selection and increase of resistance: mutant prevention concentration. J Chemother. 16(sup3):1-19. doi: 10.1080/1120009X.2004.11782371

Catry B, Cavaleri M, Baptiste K, Grave K, Grein K, Holm A, Jukes H, Liebana E, Lopez Navas A, Mackay D, Magiorakos AP, Moreno Romo MA, Moulin G, Muñoz Madero C, Matias Ferreira Pomba MC, Powell M, Pyörälä S, Rantala $M$, Ružauskas M, Sanders P, Teale C, Threlfall EJ, Törneke K, van Duijkeren E, Torren Edo J. 2015. Use of colistincontaining products within European Union and European Economic Area (EU/EEA): development of resistance in animals and possible impact on human and animal health. IntJAntimicrob Agents. 46(3):297-306.

doi: 10.1016/j.ijantimicag.2015.06.005.

Cavalieri SJ, Harbeck R, McCarter YS, Ortez JH, Rankin ID, Sautter RL, Sharp SE, Spiegel CA. 2005. Manual of Antimicrobial Susceptibility Testing. American Society for Microbiology

Chen Z, Jiang X. 2014. Microbiological safety of chicken litter or chicken litter-based organic fertilizers: A Review. Agriculture. 4: 1-29. doi:10.3390/agriculture4010001

[CODEX] Codex AlimentariousCommision. 2011. Guidelines for Risk Analysis of Foodborne Antimicrobial Resistance $\mathrm{Cac} / \mathrm{Gl}$ 77- 2011. [Internet] [Diunduhpada 13 Juli 2013]. Terdapatdalam www.fao.org.download>standards.
[DGLAHS] Directorat General of Livestock and Animal Health Services. 2016. IndeksObatHewan Indonesia Ed. IX. Jakarta (ID): KementerianPertanianRepublik Indonesia. pp. 58-599.

Drlica K. 2003. The mutant selection window and antimicrobial resistance. J AntimicrobChemother. August: 1-7.DOI: $10.1093 / \mathrm{jac} / \mathrm{dkg} 269$

[EFSA] European Food Safety Authority. 2006. Migratory birds and their possible role in the spread of highly pathogenic avian influenza. EFSA J. 357:1-46

Eiamphungporn W, Yainoy S, Jumderm C, Tiengrim S. Thamlikitkul V. 2018. Prevalence of the colistin resistance gene mcr-1 in colistin-resistant Escherichia coli and Klebsiella pneumoniae isolated from humans in Thailand. J Global Antimicrob Resistance.(15): 32-35. https://doi.org /10.1016/j.j gar.2018.06.007

[EMA] European Medicine Agency. 2013. Use of colistin products in animals within The European Union: Development of resistance and possible impact on human and animal health. 7 Westferry Circus Canary Wharf London E14 4HB United Kingdom. [Internet] [Diunduh 24 Februari 2016]. Terdapatdalamhttp:// www.ema.europa. eu/docs/en_GB/ document_library/ Report/ 2013/07/WC500146813.pdf

[EMA] European Medicine Agency. 2016. Advice on impacts of using antimicrobials in animals [Internet]. [Diunduh 7 September 2018]. Terdapatdalamwww.ema.europa.eu/ema/ index.jsp?curl=pages/ regulation/ general/ general_content_000639.jsp\&mid=WCob01ac05808 oa585

[EMA] European Medicine Agency. 2018. Guideline on the assessment of the risk to public health from antimicrobial resistance due to the use of an antimicrobial veterinary medicinal product in food producing animals (Draft 2). [Internet] [Diunduh 01 Oktober 2018]. Terdapatdalam www.ema.europa.eu/docs/en_gb/document_libr ary/scientific_guideline/2018/07/

WC500252679.pdf

Fernández L, Gooderham WJ, Bains $\mathrm{M}$, McPhee JB, Wiegand I, Hancock RE. 2010. Adaptive resistance to the "last hope" antibiotics polymyxin $\mathrm{B}$ and colistin in Pseudomonas aeruginosa is mediated by the novel two-component regulatory system ParR-ParS. Antimicrob Agents Chemother. 54(8):3372-82. doi: 10.1128/AAC.00242-10.

Ferens WA, Hovde CJ. 2011. Escherichia coli O157:H7: animal reservoir and sources of human infections. Foodborne Pathogens Dis. 8(4):465-487. 
Hadjaj L, Riziki T, Zhu Y, Li J, Diene SM, Rolain JM. 2017. Study of mcr-1 gene-mediated colistin resistance in Enterobacteriaceae isolated from humans and animals in different countries. Genes. 8:394. doi:10.3390/genes8120394

Kim YA, Yong D, Jeong SH, Lee K. 2017. Colistin resistance in Escherichia coli isolates from patients with bloodstream infection in Korea. Ann Lab Med. https://doi.org/10.3343/alm.2017.37.2.172

Lashev L, Haritova A. 2003. Pharmacokinetics of colistin in broiler chickens. Bulg J Vet Med. 6(1):21-26.

Le Devendec L, Mourand G, Bougeard S, Léaustic J, Jouy E, Keita A, Couet W, Rousset N, Kempf. 2016. Impact of colistin sulfate treatment of broilers on the presence of resistant bacteria and resistance gens in stored or composted manure. Vet Microbiol. 194:98-106. doi: 10.1016/j.vetmic.2015.11.012.

Lima Barbieri N, Nielsen DW, Wannemuehler $\mathrm{Y}$, Cavender T, Hussein A, Yan S-g, Nolan LK, Logue CM. 2017. mcr-1 identified in avian pathogenic Escherichia coli (APEC). PloS One. 12(3):e0172997. doi: 10.1371/journal.pone.0172997

Liu YY, Wang Y, Walsh TR, Yi LX, Zhang R., Spencer J, Doi Y, Tian G, Domg B, Huang X, Yu LF, Gu D, Ren $H$, Chen X, Lu L, He D, Zhou H, Liang Z, Liu JH, Shen J. 2015. Emergence of plasmid-mediated colistin resistance mechanism MCR-1 in animals and human being in china: a microbiological and molecular biology study. Lancet Infect Dis. 201. http://dx.doi.org/10/1016/S1473-3099(15)00424-7

Marshall BM, Levy SB. 2011. Food animals and antimicrobials: impacts on human health. Clin Microbiol Rev. 24(4):718-735

Moskowitz, S.M., M.K. Brannon, N. Dasgupta, M. Pier, N. Sgambati, A.K. Miller, S.E. Selgrade, S.I. Miller, M. Denton, S.P. Conway, H.K. Johansen, d N. Hoiby. 2012. Pmrb mutations promote polymyxin resistance of Pseudomonas aeruginosa isolated from colistin-treated cystic fibrosis patients. Antimicrob Agents Chemother. 56:10191030.

Napier BA, Burd EM, Satola SW, Cagle SM, Ray SM, McGann P, Pohl J, Lesho EP, Weiss DS. 2013. Clinical use of colistin induces cross-resistance to host antimicrobials in Acinetobacter baumannii. mBio. 4(3):e0oo21-13. doi:10.1128/mBio.00021-13.

[OIE] World Organization for Animal Health. 2016. Terrestrial Animal Health Code Ed. $25^{\text {th }}$. OIE. Paris, France. Chapter 6.7-6.8.
Olaitan AO, Thongmalayvong B, Akkhavong K, Somphavong S, Paboriboune P, Khounsy S, Morand S, Rolain JM. 2015. Clonal transmission of a colistinresistant Escherichia coli from a domesticated pig to a human in Laos. J AntimicrobChemother. 70:340-3404.doi:10.1016/j.ijantimicag. 2015.11.009

Palupi MF, Maheshwari H, Darusman HS, Sudarnika E, Wibawan IWT. 2018 ${ }^{\text {a }}$. Resistansi Escherichia coli TerhadapKolistin dan Deteksi Gen mcr-1 Pada BroilerAkibat Pemberian Kolistin Sulfat. J Vet Ed. Juni Vol. 19 No. 2: 167-207

Palupi MF, Darusman HS, Maheshwari H, Wibawan IWT, Sudarnika. 2018 . Human \& Veterinary Medicine International Journal of the Bioflux Society Vol. 10 Issue 4: 163-168

Palupi MF. 2019. Dissertation: Risk Assessment of Escherichia coli Resistance and MutantPreventionConcentrationStudyDue to theUsage of Colistin Sulfate in Broiler. IPB University

Palupi MF, Wibawan IWT, Sudarnika E, Maheshwari H, Darusman HS. 2019. Prevalence of mcr-1 Colistin Resistance Gene in Escherichia coli Along Broiler Meat Supply Chain in Indonesia. J BiotropiaVol. 26 No. 2 2019. DOl:http://dx.doi.org/ 10.11589/btb.2019.26.2.1054

Poirel L, Kieffer N, Brink A, Coetze J, Jayol A, Nordmann P. 2016. Genetic features of MCR-1producing colistin-resistant Escherichia coli isolates in South Africa. Antimicrob Agents Chemother. 60:4394-4397. doi:10.1128/ AAC.00444-16.

Principe L, Piazza A, Mauri C, Anesi A, Bracco S, Brigante G, Casari E, Agrappi C, Caltagirone M, Novazzi F, Migliavacca R, Pagani L, Luzzaro F. 2018. Multicenter prospective study on the prevalence of colistin resistance in Escherichia coli: relevance of mcr-1-positive clinical isolates in Lombardy, Northern Italy. Infect Drug Resist. 11:377-385.

Riemann HP, Cliver DO. 2006. Foodborne Infections and Intoxicatios $3^{\text {rd }}$ Ed. Academic Press Elsivier. pp 57-115, 719-720

Soliman ES, Sallam NH, Abouelhassan EM. 2018. Effectiveness og poultry litter amendments on bacterial survival and Eimeriaoocyst sporulation. Veterinary World. 11(8):1064-1073

Sun J, Li XP, Fang LX, Sun RY, He YZ, Lin J, Liao XP, Feng $\mathrm{Y}$, Liu YH. 2018. Co-occurrence of mcr-1 in the chromosome and on an IncHI2 plasmid: persistence of colistin resistance in Escherichia coli. Int J Antimicrob Agents. 51(6):842-847. doi: 10.1016/j.ijantimicag.2018.01.007. 
Tada T, Nhungc PH, Shimada K, Tsuchiya M, Phuong DM, Anh NQ, Ohmagari N, Kirikae T. 2017 ${ }^{\text {. Emer- }}$ gence of colistin-resistant Escherichia coli clinical isolates harboring in Vietnam. Int $J$ Infect Dis. 63:72-73.

http://dx.doi.org/10.1016/j.ijid.2017.07.003

Tada T, Uechic K, Nakasone I, Shimada K, Nakamatsu M, Kirikae T, Fujita J. 2017 ${ }^{\mathrm{b}}$. Emergence of a colistin-resistant Escherichia coli clinical isolate harboring mcr-1 in Japan. Int J Infect Dis. 63: 2122. http://dx.doi.org/10.1016/j.ijid.2017.07.003

Terveer EM, Nijhuis RHT, Crobach MJT, Knetsch CW, Veldkamp KE, Gooskens J, et al. 2017. Prevalence of colistin resistance gene ( $\mathrm{mcr}-1)$ containing Enterobacteriaceae in feces of patients attending a tertiary care hospital and detection of a mcr-1 containing, colistin susceptible E. coli. PLoS One. 12(6):e0178598.

https://doi.org/10.1371/journal.pone.0178598

Trung NV, Matamoros S, Carrique-Mas JJ, Nghia NH, Nhung NT, BichChieu TT, Mai HH, van Rooijen W,
Campbell J, Wagenaar JA, Hardon A, Nhu Mai NT, Hieu TQ, Thwaites G, de Jong MD, Schultsz C, Hoa NT. 2017. Zoonotic transmission of mcr1 colistin resistance gene from small-scale poultry farms, Vietnam. Emerg Infect Dis. 23(3):529-532.

[WHO] World Health Organization. 2016. Antimicrobial resistance. [Internet] [Diunduh 23 Oktober 2016]. Terdapat dalam http://www.who.int/mediacentre/factsheets/fs19 4/en/

[WHO] World Health Organization. 2017. Critically important antimicrobials for human medicine 5th rev. WHO. Switzerland. Licence: CC BY-NC-SA 3.0 IGO. Pp:12-37.

Zhang XF, Doi Y, Huang X, Li HY, Zhong LL, Zeng KJ, Zhang YF, Patil S, Tian GB. 2016. Possible transmission of mcr-1-harboring Escherichia coli between companion animals and human. Emerg Infect Dis. 22(9):1679-1681. DOI: http://dx.doi.org/ 10.3201/eid2209.160464. 